\title{
Structural features trigger capping of brood cells in honey bees
}

\author{
B Goetz, N Koeniger \\ Institut für Bienenkunde (Polytechnische Gesellschaft) Fachbereich Biologie der JW Goethe- \\ Universität Frankfurt a M, Karl-von-Frisch-Weg 2, 637 Oberursel 1, Germany
}

(Received 24 October 1991; accepted 14 January 1992)

\begin{abstract}
Summary - The effect on capping behaviour of the distance between the larva and the cell opening was examined. Shortened brood cells (with reduced depth) were capped earlier than normal cells. After capping, larval weight in shortened cells was lower than in control cells. Larvae of elongated cells were heavier than control larvae after capping. The results indicate that mechanical stimuli play an important role in triggering capping of cells.
\end{abstract}

Apis mellifera / brood care / cell building / capping behaviour / pheromone / mechanical stimulus

\section{INTRODUCTION}

Shortly before metamorphosis the honeybee larva turns around in its comb cell and spins its cocoon. At this time the cell opening must already be closed by a capping made of bee's wax, otherwise the larva will fall out and die. Recently Le Conte et al (1990) reported the isolation and identification of a mixture of pheromones (aliphatic fatty esters) that could induce capping behaviour. Trouiller et al (1991) have analysed the temporal secretion of several fatty esters and conclude that the role of the above-mentioned esters as pheromone "is now supported by evidence that these compounds are present in the cuticle only a few hours before the cell is capped".
Several years ago, Buchner (1953) and Gontarski (1954) suggested that the size of the larva is perceived by the bees and triggers cell capping. Data on larval growth have been reported by Bishop (1961). The increase of weight during the last day before capping is ca $75 \mathrm{mg}$. The last day's weight gain is therefore more than half $(55 \%)$ of the final larval weight at capping time. These data enable a reliable deduction to be made of larval age from larval weight.

In line with these traditional ideas the following hypothesis was tested. With the increasing growth of the bee larva the distance between the cell opening and the larva becomes smaller. This distance might constitute a suitable structural feature triggering capping behaviour. 


\section{MATERIAL AND METHODS}

The experiments were performed with Apis mellifera carnica. The colonies were kept outside in the neighbourhood of rich pollen and nectar sources. They had young mated queens.

We measured the depth of the cell using a measuring probe (fig 1). The average distance from the probe's flattened end to the apex of the pyramidal cell bottom $(1.4 \mathrm{~mm})$ was added to the measurement.

For the experiments with shortened cells we always chose 2 comb areas of $30-70 \mathrm{~cm}^{2}$ with brood cells containing 4-5-day old larvae. The distance between both areas was more than 2 $\mathrm{cm}$. One of them was randomly selected, and from the surface of this area we cut $2 \mathrm{~mm}$ of all cell walls using a razor blade. The other remained as it was and served as a control area. Opposite both comb areas we fixed wire screens parallel to the comb surface at a distance of $10 \mathrm{~mm}$ (bee space). This prevented the bees from reconstructing the shortened brood cells to normal size (fig 2). The positions of all cells were mapped using transparent foil. Elongated brood cells were prepared in the following way. The bottom of the brood cell was removed from the back side of the comb and a 5-mm deep cup made of bee's wax was

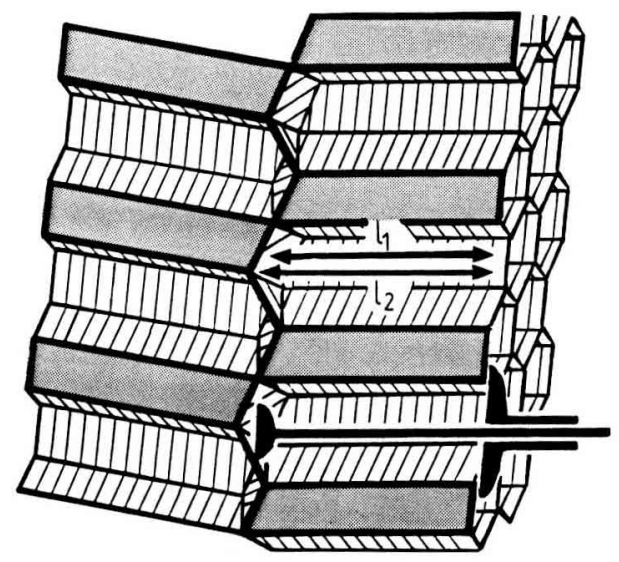

Fig 1. Measurement of cell depth. Longitudinal section of the comb. $l_{1}$ : cell depth measured by the probe. $I_{2}$ : Corrected cell depth. attached. This cup had a diameter of about 5 $\mathrm{mm}$ and formed the new cell bottom to the now elongated cell. To prevent bees from interfering, the back side of the comb was sealed by filling cells with liquid bee's wax (fig 3 ). Afterwards we grafted 2-3-day-old larvae into the prolonged cells and placed the comb back into the colony. Larvae of the same size and batch were grafted into normal (unchanged) brood cells as controls. Controls and experimental cells were on the same comb and kept in the same colony.

For determination of the onset of capping we used the diameter of the cell opening. A smaller than $4.5 \mathrm{~mm}$ diameter was used as an indication of commencement of capping. We examined 168 shortened brood cells from 8 comb areas in 2 colonies and compared them to 171 normal brood cells in the control areas.

To measure the larval weight we examined brood cells every $24 \mathrm{~h}$ and opened the newly capped cells. The larvae were carefully removed and their weight as well as the cell depth was determined.

Altogether, 93 shortened brood cells of 7 comb areas out of 3 colonies were compared to the corresponding control cells. Twentyone elongated cells of 2 colonies and the appropriate control cells were treated in the same way.

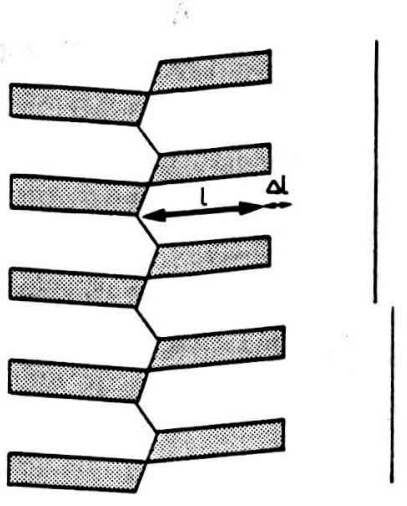

Fig 2. Shortened brood cells and control cells. Longitudinal section of the comb. A wire screen was fixed parallel to comb at $10 \mathrm{~mm}$ distance. l: cell depth. $\Delta l$ : amount of shortening. 

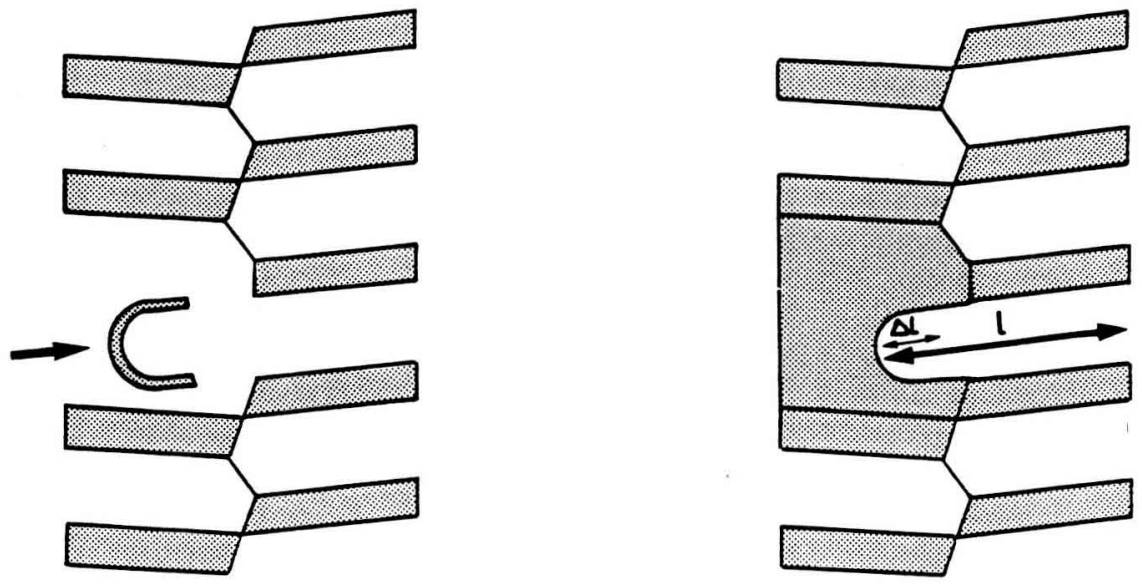

Fig 3. Elongated brood cells. Longitudinal section of the comb. Left: attaching of a cup out of bee wax. Right: sealing of the back side of the comb area by pouring liquid wax. I: cell depth; $\Delta$ : amount of elongation.

\section{RESULTS}

Cell capping behaviour is prepared by hive bees which deposit bee wax at the rim of the cell opening. Later, this wax is drawn out. The rims are broadened and the diameter of the cell opening is reduced. At a diameter of $4.5 \mathrm{~mm}$ the capping behaviour is at its peak activity. Regularly, within $2 \mathrm{~h}$ after the $4.5 \mathrm{~mm}$ diameter stadium, cell capping is completed (Meyer and Ulrich, 1952). We compared normal cells to shortened cells at the time of capping. A significantly higher number of the shortened cells already had cell opening diameters smaller than $4.5 \mathrm{~mm}\left(\chi^{2}=8.5, P<0.01\right)$ (table I). This indicates that capping starts earlier in shortened cells.

After capping, the larvae of the shortened cells had a significantly lower weight $(t=9.2 ; P<0.001)$ (table II). Bees had extended the shortened brood cells by about $0.5 \mathrm{~mm}$. So at the capping stage the aver- age difference in depth compared to controls was about $1.5 \mathrm{~mm}$.

Elongated brood cells were also shortened by about $0.5 \mathrm{~mm}$ by the bees. So at capping time the average difference between elongated cells and control cells was $4.5 \mathrm{~mm}$. The larvae in the elongated cells were significantly heavier than those in normal cells $(t=3.17 ; P<0.005)$ (table III).

Table I. Start of cell capping of shortened brood cells.

\begin{tabular}{lcc}
\hline & $\begin{array}{l}\text { No of cells } \\
\text { with opening } \\
<4.5 \mathrm{~mm}\end{array}$ & $\begin{array}{l}\text { No of cells } \\
\text { with opening } \\
>4.5 \mathrm{~mm}\end{array}$ \\
& & \\
\hline $\begin{array}{l}\text { Shortened cells } \\
\text { Control cells }\end{array}$ & 85 & 83 \\
& 59 & 112 \\
\hline
\end{tabular}

$\chi^{2}=8.5 ; P<0.01$. 
Table II. Cell depth and larval weight after capping in shortened brood cells.

\begin{tabular}{lcc}
\hline & $\begin{array}{c}\text { Cell depth } \\
(\mathrm{mm})\end{array}$ & $\begin{array}{c}\text { Larval weight } \\
(\mathrm{mg})\end{array}$ \\
\hline $\begin{array}{l}\text { Shortened } \\
\text { cells }(n=93)\end{array}$ & $11.8 \pm 0.4$ & $148.7 \pm 6.9$ \\
$\begin{array}{l}\text { Control } \\
\text { cells }(n=83)\end{array}$ & $13.3 \pm 0.4$ & $157.9 \pm 6.3$ \\
\hline
\end{tabular}

$t=9.2 ; P<0.001$.

\section{DISCUSSION AND CONCLUSION}

In normal brood cells, the distance between larva and cell opening depends on the larval weight. The weight corresponds to the age of the larva and pheromones which trigger capping are found in the larval cuticle only few hours before capping (Trouiller et al, 1991). We interfered experimentally with the correlation between the distance (larva-cell opening) and larval age (and age-related pheromones) by changing the cell's depth. In the case that capping depends entirely on pheromones, brood cells should be capped according to larval age. Alternatively, if cell capping

Table III. Cell depth and larval weight after capping in elongated brood cells.

\begin{tabular}{lll}
\hline & $\begin{array}{l}\text { Cell depth } \\
(\mathrm{mm})\end{array}$ & $\begin{array}{l}\text { Larval weight } \\
(\mathrm{mg})\end{array}$ \\
\hline $\begin{array}{l}\text { Elongated } \\
\text { cells }(n=21)\end{array}$ & $18.3 \pm 1.6$ & $173.8 \pm 14.5$ \\
$\begin{array}{l}\text { Control } \\
\text { cells }(n=29)\end{array}$ & $13.8 \pm 0.4$ & $162.4 \pm 9.2$ \\
\hline
\end{tabular}

$t=3.17 ; P<0.005$. could be advanced by shortening or delayed by elongation of cell depth, structural features would play an important role in triggering capping behaviour.

A comparison of shortened and normal cells during the process of capping showed that capping behaviour started earlier in shortened cells. After capping, larvae in shortened brood cells had a $9 \mathrm{mg}$ lower weight than those in control cells. Using the data of Bishop (1961) on the correlation between larval weight and larval age, this corresponds to an approximately 3-h advance in capping time. Elongated brood cells resulted in an increased larval weight. This suggests a later capping of elongated cells compared to control cells. An extrapolation of Bishop's (1961) data resulted in a 3.5-h delay in capping, on condition that larvae continued to increase their weight at a similar rate. Therefore the change in cell depth could alter cell capping by about $6 \mathrm{~h}$.

Bees responded to a change in cell depth in the expected manner. We conclude that the distance between larva and cell opening constitutes a structural feature which is involved in triggering capping behaviour. Our experiments support the hypothesis of Buchner (1953) and Gontarski (1954). Further, larval pheromones in the cuticle (methyl and ethyl fatty acid esters) are not the only parameter used by the workers to determine the precise time of capping.

In some other brood care behaviour, structural features and pheromones act synergistically. Mechanical stimuli caused by the weight of the larva are essential for the function of the pheromone, 1,2-dioleyl3-palmitoyl-glycerin, releasing warming behaviour (Koeniger, 1978; Koeniger and Veith, 1983, 1984). Also in ants (Brian, 1975), the larval turgor (mechanical stimulus) and chemical factors are jointly required for brood recognition. 
Résumé - Des caractéristiques structurales déclenchent l'operculation des cellules de couvain de l'abeille. En filant son cocon, la larve d'abeille effectue des mouvements dans sa cellule et, si à ce moment-là les cellules ne sont pas operculées par les ouvrières, les larves tombent de la cellule. Le Conte et al (1990) ont isolé et identifié différentes phéromones qui déclenchent l'operculation. Trouiller et al (1991) ont étudié l'évolution dans le temps de la sécrétion de ces substances et en ont déduit que le moment de l'operculation était déterminé par ces phéromones qui n'étaient présentes dans la cuticule larvaire que quelques heures auparavant. Buchner (1953) et Gontarski (1954) pensent par contre que la taille de la larve est perçue par les ouvrières et déclenche l'operculation. Lorsque la larve grossit, la distance entre la larve et le bord de la cellule diminue. Cette distance pourrait constituer une caractéristique structurale capable de provoquer le comportement d'operculation; c'est ce que nous avons voulu tester.

Pour cela nous avons raccourci de 2 $\mathrm{mm}$ et allongé de $5 \mathrm{~mm}$ des cellules de couvain (figs 2 et 3 ). Le moment de l'operculation des cellules raccourcies a été comparé à celui des cellules témoins. On a déterminé dans les 2 groupes le nombre de cellules qui présentaient déjà un début d'operculation (diamètre de l'ouverture $<4,5 \mathrm{~mm}$ ). Celles-ci étaient significativement plus nombreuses parmi les cellules raccourcies que parmi les témoins (tableau I), ce qui indique que l'operculation commence plus tôt dans les cellules raccourcies. On a également comparé le poids des larves dans les 3 types de cellules peu de temps après l'operculation. Les larves des cellules raccourcies pesaient en moyenne $9 \mathrm{mg}$ de moins, celles des cellules allongées $11 \mathrm{mg}$ de plus que les larves des cellules témoins normales (tableaux II et III). D'après les données de Bishop (1961), cela indique que l'operculation des cellules raccourcies a lieu environ $3 \mathrm{~h}$ plus tôt. De même le poids plus élevé des larves des cellules allongées correspond à une operculation retardée d'environ $3,5 \mathrm{~h}$. Le moment précis de l'operculation est dans une large mesure déterminé par des caractéristiques structurales et non par des phéromones. Dans l'ensemble pourtant l'operculation, comme le comportement de soins au couvain (Koeniger, 1978; Koeniger et Veith, 1983, 1984), est déclenchée par la synergie de stimuli mécaniques et de phéromones.

\section{Apis mellifera / soin au couvain / com- portement d'operculation / stimulus mé- canique / phéromone}

\section{Zusammenfassung - Strukturmerkma- le beeinflussen das Verdeckeln von} Brutzellen der Honigbiene. Beim Spinnen ihres Kokons bewegen sich die Larven in den Zellen. Sind die Zellen zu dieser Zeit von den Arbeiterinnen nicht verschlossen, fallen die Larven bei den Spinnbewegungen aus den Zellen heraus. Le Conte et al (1990) berichteten von der Isolation und Identifikation verschiedener Pheromone, die das Verdeckeln auslösen. Trouiller et al (1991) bestimmten die zeitliche Sekretion dieser Substanzen und folgerten daraus, daß auch der Zeitpunkt des Verdeckelns durch diese Pheromone bestimmt wird, die erst wenige Stunden zuvor in der larvalen Kutikular auftreten. Buchner (1953) und Gontarski (1954) dagegen vermuteten, daß die Larvengröße von den Arbeiterinnen wahrgenommen wird und das Verdeckeln auslöst. Mit dem Wachstum der Larven nimmt der Abstand zwischen Larve und Zellrand ab. Der Einfluß dieses Abstandes auf den Verdecklungszeitpunkt wurde geprüft. 
Dazu wurden Brutzellen sowohl verkürzt als auch verlängert (Abb 2 und 3 ). Der Verdecklungszeitpunkt verkürzter Zellen wurde mit dem entsprechender Kontrollzellen verglichen. Dazu wurde in beiden Gruppen zur gleichen Zeit die Anzahl von Zellen bestimmt, die bereits einen Anfang des Zelldeckels zeigten. Bei verkürzten Zellen waren dies signifikant mehr Zellen als in der Kontrollgruppe (Tabelle I). Arbeiterinnen beginnen demnach bei verkürzten Zellen vorzeitig mit dem Verdeckeln. Weiter wurde kurz nach dem Verschließen das Gewicht von Larven aus verkürzten, verlängerten und Kontrollzellen bestimmt. Larven aus verkürzten Zellen waren durchschnittlich $9 \mathrm{mg}$ leichter. Larven aus verlängerten Zellen dagegen waren durchschnittlich $11 \mathrm{mg}$ schwerer als Vergleichslarven aus normalen Zellen (Tabelle II und III). Nach den Daten von Bishop (1961) entspricht dies einem um etwa 3 Stunden verfrühten Verdecklungszeitpunkt bei verkürzten Zellen.

Entsprechend weist das größere Gewicht der Larven aus verlängerten Zellen auf einem um etwa 3,5 Stunden späteren Verdecklungszeitpunkt hin. Demnach wird der genaue Zeitpunkt des Verdeckelns der Brutzellen weitgehend durch Struktureigenschaften der Brutzelle und nicht durch Pheromone bestimmt. Insgesamt dürfte jedoch das Verdeckeln ebenso wie das Wärmeverhalten (Koeniger, 1978; Koeniger und Veith, 1983, 1984) durch ein Zusammenspiel von mechanischen Reizen und Pheromonen ausgelöst werden.
Apis mellifera / Brutpflege / Verdecklungsverhalten / mechanischer Reiz / Pheromone

\section{REFERENCES}

Bishop GH (1961) Growth rates of honey bee larva. J Exp Zool 146, 11-20

Brian MV (1975) Larval recognition by workers of the ant Myrmica. Anim Behav 23, 745-756

Buchner R (1953) Beeinflussung der Größe der Arbeitsbiene durch Raum- und Nahrungsmangel während der Larvenzeit. Roux Arch Entw Mech Organ 146, 544-579

Gontarski H (1954) Untersuchungen über die Verwertung von Pollen und Hefe zur Brutpflege der Honigbiene. $Z$ Bienenforsch 2, 161-180

Koeniger N (1978) Das Wärmen der Brut bei der Honigbiene (Apis mellifera L). Apidologie 9 , 305-320

Koeniger N, Veith HJ (1983) Glyceryl-1,2dioleate-3-palmitate, a brood pheromone of the honey bee (Apis mellifera L). Experientia 39, 1051-1052

Koeniger N, Veith HJ (1984) Spezifität eines Brutpheromons und Bruterkennung bei der Honigbiene (Apis mellifera L). Apidologie 15, 205-210

Le Conte $Y$, Arnold G, Trouiller J, Masson C, Chappe B (1990) Identification of a brood pheromone in honeybees. Naturwissenschaften 77, 334-336

Meyer W, Ulrich W (1952) Zur Analyse der Bauinstinkte unserer Honigbiene. Untersuchungen über die "Kleinbauarbeiten". Naturwissenschaften 39, 264

Trouiller J, Arnold G, Le Conte $Y$, Masson C, Chappe $B$ (1991) Temporal pheromonal and kairomonal secretion in the brood of honeybees. Naturwissenschaften $78,368-370$ 